\title{
Completed By
}

National Cancer Institute

\section{Source}

National Cancer Institute. Completed By. NCI Thesaurus. Code C73470.

Indicates the person or authoritative body who made completed something. 